\title{
BIRD COMMUNITIES AND VEGETATION COMPOSITION IN THE URBAN FOREST ECOSYSTEM: CORRELATIONS AND COMPARISONS OF DIVERSITY INDICES
}

\author{
OLENA BLINKOVA $^{1 *}$, TETYANA SHUPOVA ${ }^{2}$ \\ ${ }^{1}$ National University of Life and Environmental Sciences of Ukraine, Kyiv, Ukraine; e-mail: elena.blinkova@gmail.com \\ ${ }^{2}$ Institute for Evolutionary Ecology NAS of Ukraine, Kyiv, Ukraine \\ * Author for correspondence
}

\begin{abstract}
Blinkova O., Shupova T.: Bird communities and vegetation composition in the urban forest ecosystem: correlations and comparisons of diversity indices. Ekológia (Bratislava), Vol. 36, No. 4, p. 366-387, 2017.

Assessment of relationships and diversity indices between bird's communities and composition of the forest ecosystem is an important subject of synecological research to identify the intensity of human impact on the flora and fauna. Urban recreation is one of the major causes of violation of the structural and functional integrity of the forest ecosystem. Studies of avian complex and phytocoenosis have focused on the impact of urban recreation on the compositions of tree, shrub and herbaceous layers and species, trophic and ecological compositions of breeding-birds and feeding-birds communities. This paper compares the measurement of the diversity of bird communities and forestry vegetation (diversity indices, dominance indices, distribution uniformity indices) of intensive, medium, moderate and weak stages of recreational transformation of biotope. The stands formed Quercus robur L., Carpinus betulus L., Acer platanoides L., Tilia cordata L. The floristic list comprised 78 grass species. A total number of 43 species of avifauna including 37 breeding species are observed during the study. There were significant correlations between vertical heterogeneity of tree distribution and abundance, species richness and nesting density of birds. The interrelationship between species diversity of birds and floristic richness was also confirmed.
\end{abstract}

Key words: communities, plant vegetation, avifauna, indexes of diversity, recreational transformation.

\section{Introduction}

The significant changes in the conditions of existence of biota species occurred under intensive human impact on the environment. These changes exhibit pollution, destruction of soil covering and plant formation, which leads to ecosystem transformation. In this context, forest ecosystem is an essential element to study. Forests play a core role in biosphere stability because of the significant area, capacity, duration of development, forest productivity and complexity of structural and functional organisation (Migunova, 1993; Mirkin et al., 2002). The response of a forest ecosystem to changing environmental conditions is determined by its biological resources (Ramenskii, 1971; Rabotnov, 1992; Mirkin et al., 2002; Blinkova, 2014). 
Urban recreation is one of the main anthropogenic factors that lead to a significant transformation of structural and functional integrity of natural and seminatural forests in Ukraine. Furthermore, numerous studies in forested areas have emphasised the importance of urbanisation gradient to examine the response of the biotic community. It is well known that mechanical human impact on forest is manifested in trampling of leaf litter, surface soil compaction and mechanical damage to trees and herbaceous cover (Rusin, 2003; Blinkova, 2014; Lavrov et al., 2016).

All these violations cause changes in ecological regimes, particularly in communities of birds. When evaluating the biodiversity of forest ecosystem subjected to gradients of recreational disturbance, birds are a particularly advantageous taxonomic group that is visually and acoustically conspicuous and can thus provide an efficient means of evaluating habitat change in forest systems (Sekercioglu, 2006; Etterson et al., 2007; Fischer et al., 2007; Gardner et al., 2008; Whelan et al., 2008). Increasing urbanisation often results in simplified habitats, a community of birds with fewer species dominated by abundant non-native species and changes in ecological groups of birds (guilds) (Marzluff et al., 1998). Studies of breeding birds are particularly relevant to create the dependencies between the transformation of phytocoenosis and avifauna. Specific features of breeding bird density distribution in urban forest reflected heterogeneity of their populations with respect to connections with nesting biotopes (Camprodon, Brotons, 2006; Shupova, 2017).

Variations of characteristics of the forest ecosystem, formed under the influence of urban recreation, have shown the relationships between phytocoenotic parameters and species diversity and density of nesting birds (Conner, Dickson, 1997; Chaplygina et al., 2016).

Many researchers consider that the degree of structural complexity of phytocoenosis is a significant index of relationships between bird's communities and forest compositions (James, Wamer, 1982; Hinsley et al., 1995) and the approaches to issues based on the measurement phytocoenotic parameters and species diversity and density of breeding birds (Kurlavichus, 1986; Fuller, Moreton, 1987; Catsadorakis, 1997; Walther, 2002). The integral criterion that combines several measurement values, in particular indices of vertical and horizontal heterogeneity, is also used (MacArthur R., MacArthur J., 1961; Wilson, 1974; O'Connor, 1981; Willson et al., 1994).

Understanding bird-vegetation interactions is crucial in assessing human activities on forest ecosystem, but it is also important to understand how these interactions change under urboecosystem conditions. Therefore, this research was conducted to evaluate correlations and indices of diversity between bird communities and vegetation composition according to intensity of recreational impact.

\section{Material and methods}

\section{Experimental site}

Study sites were all located within the Vinnytsia city. This forest is located inside the city. The first information about the nature and historical development of city is presented by Marczynski (1977). Community of Querceta roboris formation covered the city area in the past. Vinnytsia is located on the right and left banks of the Southern Bug river at the Forest-Steppe zone (Erofeev, 1960). The area of the city is $113.15 \mathrm{~km}^{2}$, of which $14.78 \mathrm{~km}^{2}$ are urban forest. Study area is located on the geobotanical zone of European broad-leaved forests, which is represented by the 
sub-province of mixed coniferous-broad-leaved forests of Polissya (Barbarich, 1977) (Fig. 1). The climate is a semicontinental type. Gray podsolic soil and podsolised chernozem are the main soil types in Vinnytsia.

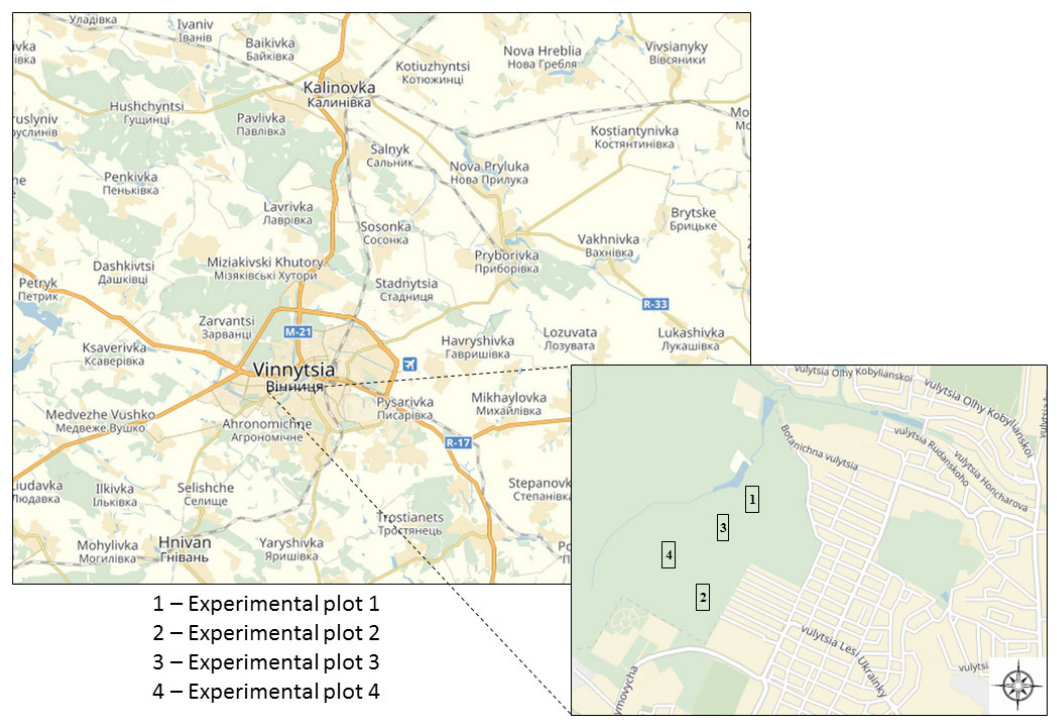

Fig. 1. Geographical distribution of the studied area. The symbols indicate the location and number of experimental plots.

T a ble 1. Recreational transformation of urban forest ecosystem is shown via basic characteristics of the change in state of herbaceous cover, leaf-litter, tree stratum, undergrowth and soil surface. Degradation stages of transformation are shown.

\begin{tabular}{|l|l|l|l|}
\hline \multirow{2}{*}{$\begin{array}{l}\text { Degradation } \\
\text { stage }\end{array}$} & \multicolumn{1}{|c|}{ Herbaceous cover and leaf-litter } & \multicolumn{1}{|c|}{$\begin{array}{c}\text { Tree stratum } \\
\text { and undergrowth }\end{array}$} & \multicolumn{2}{|c|}{ Soil surface } \\
\cline { 2 - 4 } 1 & $\begin{array}{l}\text { Full species composition of herbaceous } \\
\text { plant community, plant projective cover is } \\
90-100 \%, \text { leaf-litter is not broken }\end{array}$ & $\begin{array}{l}\text { Trees are healthy, under- } \\
\text { growth is numerous and of } \\
\text { different ages }\end{array}$ & $\begin{array}{l}\text { I stage of } \\
\text { degradation }\end{array}$ \\
\hline \multirow{2}{*}{3} & $\begin{array}{l}\text { Appearance of ruderal or meadow herba- } \\
\text { ceous species, projective cover is } 80-90 \%, \\
\text { leaf-litter begins to trample down }\end{array}$ & $\begin{array}{l}\text { Trees are weakened, un- } \\
\text { dergrowth is numerous but } \\
\text { not of different ages }\end{array}$ & $\begin{array}{l}\text { II stage of } \\
\text { degradation }\end{array}$ \\
\hline \multirow{2}{*}{3} & $\begin{array}{l}\text { Share of ruderal or meadow herbaceous } \\
\text { species is 5-10\%, projective cover is 70-80\%, } \\
\text { leaf-litter is trampled down }\end{array}$ & $\begin{array}{l}\text { Trees are weakened or } \\
\text { heavily weakened, under- } \\
\text { growth is limited }\end{array}$ & $\begin{array}{l}\text { III stage of } \\
\text { degradation }\end{array}$ \\
\hline 5 & $\begin{array}{l}\text { Share of ruderal or meadow herbaceous spe- } \\
\text { cies is } 10-20 \%, \text { projective cover is 50-70\%, } \\
\text { leaf-litter begins to deteriorate }\end{array}$ & $\begin{array}{l}\text { Trees are heavily weak- } \\
\text { ened, low viability of } \\
\text { undergrowth is located } \\
\text { clumps }\end{array}$ & $\begin{array}{l}\text { IV stage of } \\
\text { degradation }\end{array}$ \\
\hline & $\begin{array}{l}\text { Ruderal or meadow herbaceous species are } \\
\text { dominant species, projective cover is 0-50\%, } \\
\text { leaf-litter is completely absent }\end{array}$ & $\begin{array}{l}\text { Trees are heavily weakened } \\
\text { or wilting with signifi- } \\
\text { cant mechanical damage, } \\
\text { undergrowth is absent }\end{array}$ & $\begin{array}{l}\text { V stage of } \\
\text { degradation }\end{array}$ \\
\hline
\end{tabular}




\section{Data collection and processing}

An ecological profile consisting of four experimental plots (EPs), depending on the recreational gradient in the urban forest, was established in accordance with the principles of comparative ecology (Anuchin, 1977). According to reconnaissance observations of recreational data, the EPs were divided into four types, designated as intensive (EP1; 0,72 ha), medium (EP2; 0,75 ha), moderate (EP3; 0,73 ha) and weak (EP4; 0,72 ha) stages of recreational transformation of biotope. Lake 'Sotsky' is located on the territory of the investigated forest. The shores of the lake created nesting and feeding stations for water birds. An intensive transformation of the phytocoenosis at EP1 is associated with the recreational impact of people. In June (12-18) 2016, we collected data from these EPs. Birds were nesting during this period. Passeriformes actively were singing or feeding chicks. At the same time, they were clearly visible.

Observations of the birds were carried out during morning (7.00-11.00) or evening (18.00-19.30). The weather conditions were favourable for bird surveys. The wind was absent. The air temperature was $25-28^{\circ} \mathrm{C}$. The song activity of Passeriformes was high. The newly hatched chicks were marked together with the registered pairs.

By taking into account the basic characteristics of recreational changes in the elements of structural and functional organisation of urban forest ecosystem (the state of tree stratum, undergrowth, soil surface layer, herbaceous cover and leaf litter), the level of recreational transformation rate was specified for each EP. The stages of the recreational transformation were assessed according to Rusin (2003) (Table 1). The state of the soil surface layer was determined according to Polyakov (2009).

Vegetation surveys. Herbaceous layer assessment

Plant complex of all EPs was established according to the botanical detailed route method (Neshataev, 1987; Didukh, 1994; Mirkin et al., 2002). Taxa nomenclature was adopted from Mosyakin and Fedoronchuk (1999), taking into account the existing 'International Code of Nomenclature for algae, fungi, and plants' (2012). To appraise the diversity of species, the Braun-Blanquet scale (Braun-Blanquet, 1964) was used. The adventive index was calculated as a percentage of the adventitious species encountered at EP (Burda, 2006).

\section{Assessment of tree health and vitality composition}

Tree health (category of tree state) was assessed according to the Sanitary Forest Regulation of Ukraine (1995). The stand state index was calculated as a sum of the values of the tree state index of trees in a certain category divided by the total number of examined trees:

$$
I_{c}=\frac{\sum k_{i} \cdot n_{i}}{N},
$$

where $\mathrm{k}_{\mathrm{i}}$ is the category of tree state $(\mathrm{I}-\mathrm{VI}) ; \mathrm{n}_{\mathrm{i}}$ is the number of trees in a certain category of tree state and $\mathrm{N}$ is the total number of trees.

The stands with index values ranging from 1 to 1.5 are considered as healthy (I), $1.51-2.50$ as weaker ones (II) , 2.51-3.50 as seriously weakened ones (III) , 3.51-4.50 as wilting ones (IV), $4.51-5.50$ as recently dead (V) and 5.51-6.50 old dead stands (VI).

The weighted average of Kraft classes (WAKC; vitality of tree vegetation) was calculated for each category as a sum of the number of trees in each Kraft class multiplied by the index of the state of the stand (I-V) and divided by the total number trees in a certain state:

$$
W A K C=\frac{\sum k_{k} \bullet \boldsymbol{t}}{n_{i}},
$$

where $k_{k c}$ is the number of trees in each Kraft class, $I_{c}$ is the index of the stand state and $n_{i}$ is the number of trees in a certain state category. The trees in each category were divided into five Kraft classes. Classes $\mathrm{Va}$ and $\mathrm{Vb}$ were combined into class V.

For each stand, the forest mensuration parameters were derived as follows: age (A); the total number of trees $(\mathrm{N})$, the weighted average of diameters $\left(\mathrm{D}_{\text {ave }}\right)$, height $\left(\mathrm{H}_{\text {ave }}\right)$, diameter and height range $\left(\mathrm{D}_{\min }-\mathrm{D}_{\max } ; \mathrm{H}_{\min }-\mathrm{H}_{\max }\right)$, standard deviation (SD), stand density $(\mathrm{P})$, stand basal area as a sum of tree basal areas $\left(\mathrm{G}_{\mathrm{n}}\right)$, weighted average 
distance between the trees $(\mathrm{AD})$ and total number of undergrowth. The morphometric parameters were measured by an optical altimeter (Suunto PM-5;Waldmeister 100alu Calipers). Mechanically damaged woody plants were the trees and bushes with cut living branches; the injuries on the stem reach cambium.

\section{Bird surveys}

Taxa nomenclature of birds was adopted by 'International Code of the Zoological Nomenclature' (1999). The species of birds and the search for their nests in tree canopies visually were determined using binoculars Barska X-Trail 10x50 Reverse Porro. The audio definition of birds' voices (mp3) was used for the acoustic identification of species.

Bird communities of all EPs was researched according to the transect method (Novikov, 1953; Järvinen, Väisänen, 1975; Bibby et al., 2000; Hiby, Krishna, 2001). Transect surveys were used to compare the differences in bird between EPs. The length of transect was $1,000 \mathrm{~m}$. The width on both sides of the direction of movement was $50 \mathrm{~m}$. The density of bird feeding stations was determined by the number of individuals of each species per $1 \mathrm{~km}$ transect. Singing male was counted as a nesting pair for passerine species (Novikov, 1953). The status of the species (breeding, feeding and migration) was determined by the behaviour or presence of a nest for non-Passeriformes species. Community of breeding birds and community of feeding birds were analysed separately.

We also classified bird species into different categories (ecological groups) according to the patterns of microhabitat choice (Zavjalov et al., 2005; Camprodon, Brotons, 2006; Bragin, Bragina, 2014; Muntaner et al., 1983; Snow, Perrins, 1998; Shirihia et al., 2001; Atemasova, 2015). The category of water birds includes waterfowl and wading birds that live on or around water. Woody nesters are species of the shrub layer of the undergrowth or tree layer. The individuals of this category are divided into two groups: tree canopies nesters and tree hollow nesters. The tree hollow nesters are divided into primary, birds that make hollows (Picidae), and secondary ones, those that settle in ready-made hollows. The category of ground nesters includes birds associated with the forest open habitats. The category of cavity nesters includes birds associated with vertically dissected relief (cracks in rocks, trees, stumps).

We classified bird species into different categories according to the type of feeding: insectivorous birds (these birds feed insects and bugs that contain meat, Scolopacidae, Motacillidae, Sylviidae, Muscicapidae), granivorous birds (these birds feed grain of plants, Columbidae), birds with mixed type of feeding (e.g. Picidae, Paridae, Fringillidae), predatory birds (these birds hunt and feed on rodents and other small animals, Falconiformes, Strigiformes), fish-eating birds (Ardea cinerea, Alcedo atthis) and pantophagous birds (these birds feed all types of feeding, Corvidae) (Camprodon, Brotons, 2006).

Species of birds forming synanthropic and natural populations were isolated simultaneously into the group of hemysynanthropes (Klausnitzer, 1990). A list of birds protected by the 'International Conventions for the Protection of Birds' was presented.

\section{Statistical analyses}

For the assessment of plant and birds biodiversity, various methods and indices are available. In this study, the indices of diversity, dominance and equalisation were used for each EP (Magurran, 1998):

1. relative abundance of species or guild

$$
P_{\mathrm{i}}=\frac{N_{i}}{N}
$$

2. the indices of dominance

$$
\begin{aligned}
& \text { Berger-Parker } \\
& D s=\sum_{i=1}^{S}\left[\frac{N_{i}}{N}\right]^{2} \text { Simpson } \\
& D m=\frac{(N-U)}{(N-\sqrt{N})}, U=\sqrt{\sum N_{i}^{2}} \text { McIntosh }
\end{aligned}
$$


3. the indices of diversity

$$
\begin{aligned}
& H=-\sum p_{i} \log _{2} \rho_{i} \text { Shannon } \\
& D_{M n}=\frac{S}{\sqrt{N}} \text { Menchinick } \\
& D_{M r}=\frac{(S-1)}{\ln N} \text { Margalef } \\
& c=\frac{1}{D_{S}} \text { Simpson }
\end{aligned}
$$

4. the indices of evenness

$$
\begin{aligned}
& E=\frac{H^{i}}{\ln S} \text { Pielou } \\
& U=\sqrt{\sum N_{i}{ }^{2}}, E=\frac{N-U}{N-\frac{N}{\sqrt{S}}} \text { McIntosh }
\end{aligned}
$$

where $\mathrm{N}_{\mathrm{i}}$ is the density of the species in communities, $\mathrm{N}$ is the total number of individuals ( the number of individuals per hectare for plants and the number of individuals per kilometre for the birds), $\mathrm{N}_{\max }$ is the maximum value of $\mathrm{N}_{\mathrm{i}}, \mathrm{U}$ is the McIntosh index of diversity; $p_{\mathrm{i}}$ is the ratio of each species; $\mathrm{S}$ is the total number of the species; $\mathrm{D}_{\mathrm{s}}$ is the Simpson index of dominance; $H^{\prime}$ is the Shannon's index of diversity.

Index of horizontal heterogeneity of vegetation (IHH) and index of vertical heterogeneity of vegetation (IVH) were calculated in order to describe the vegetation composition in the urban forest ecosystem as the feeding and breeding stations of birds (Blondel, Cuvillier, 1977; Erdelen, 1984). IVH is the Shannon's index for vertical vegetation distributions, taking the number of vegetation touches at each height as individuals in that class. IHH is the coefficient of variation of point-centred quarter distance between the trees (AD)

$$
I H H=\frac{S \cdot D \cdot A D}{A D_{\text {ave }}}
$$

As higher habitat structural heterogeneity often increases bird species richness because of the presence of more diverse nesting and foraging resources, IHH is lowest if trees are distributed uniformly and higher for a random distribution (Sekercioglu, 2002).

\section{Results}

\section{Assessment of stands morphometric parameters}

Surveys were conducted in hornbeam-oak (Carpinus betulus L., Quercus robur L.) forest. The stands at all EP were two storeyed. The age structure of stands consisted mainly of trees of the same age (50-70 years). The first storey consists of Q. robur and Carpinus betulus. The second storey consists of Acer platanoides L. and Tilia cordata L. The exploratory analysis of empirical material along the gradient of recreational transformation showed that the highest forest stands parameters (diameter, height, total number of trees and others) was in EP4. The magnitude of stand density reduced from 0.85 (EP4) to 0.5 (EP1) because of the decrease in the proportion of Quercus robur (Table 2). The stand basal area was also reduced. 
$\mathrm{T}$ a b l e 2. Characteristic of the dominant tree vegetation in different experimental plots. Variation of forest mensuration parameters for Quercus robur, Carpinus betulus, Abies alba, Acer platanoides and Tilia cordata is presented.

\begin{tabular}{|c|c|c|c|c|c|c|c|c|c|}
\hline No. EP & Species & $\begin{array}{c}\mathrm{A} \\
\text { (years) }\end{array}$ & $\begin{array}{c}\mathbf{H} \\
(\mathbf{m})\end{array}$ & $\begin{array}{c}\mathbf{H}_{\min }-\mathbf{H}_{\max } ; \\
\text { SD (m) }\end{array}$ & $\begin{array}{c}\mathrm{D} \\
(\mathrm{cm})\end{array}$ & $\begin{array}{c}\mathrm{D}_{\min }-\mathrm{D}_{\max } \\
\mathrm{SD}(\mathrm{cm})\end{array}$ & $\begin{array}{c}\mathrm{N} \\
\text { (pieces) }\end{array}$ & $\begin{array}{c}\mathrm{G}_{\mathrm{n}}, \\
\left(\mathrm{m}^{2} \mathbf{h a}^{-1}\right)\end{array}$ & $\mathbf{P}$ \\
\hline \multirow{4}{*}{1} & Q. robur & 70 & 26.5 & $\begin{array}{c}24.1-27.8 \\
1.45 \\
\end{array}$ & 28.5 & $\begin{array}{c}23.5-35.5 \\
5.65\end{array}$ & 180 & \multirow{4}{*}{298.1} & \multirow{4}{*}{0.50} \\
\hline & C. betulus & 70 & 23.2 & $\begin{array}{c}22.0-25.1 ; \\
1.76\end{array}$ & 29.1 & $\begin{array}{c}23.4-34.2 \\
4.56\end{array}$ & 160 & & \\
\hline & A. platanoides & 50 & 22.1 & $\begin{array}{c}20.0-24.1 ; \\
1.55 \\
\end{array}$ & 27.5 & $\begin{array}{c}21.6-42.1 ; \\
5.98 \\
\end{array}$ & 110 & & \\
\hline & T. cordata & 50 & 19.9 & $\begin{array}{c}17.2-21.1 \\
2.43 \\
\end{array}$ & 27.3 & $\begin{array}{c}19.3-31.8 \\
6.45\end{array}$ & 55 & & \\
\hline \multirow{4}{*}{2} & Q. robur & 70 & 27.8 & $\begin{array}{c}25.3-28.1 ; \\
1.78 \\
\end{array}$ & 39.6 & $\begin{array}{c}28.3-44.5 \\
6.78\end{array}$ & 355 & \multirow{4}{*}{355.6} & \multirow{4}{*}{0.65} \\
\hline & C. betulus & 70 & 22.0 & $\begin{array}{c}20.3-22.4 \\
1.67\end{array}$ & 24.0 & $\begin{array}{c}18.3-29.5 \\
5.77\end{array}$ & 150 & & \\
\hline & A. platanoides & 60 & 16.5 & $\begin{array}{c}14.2-18.5 ; \\
2.01\end{array}$ & 19.0 & $\begin{array}{c}15.5-27.3 \\
5.11\end{array}$ & 85 & & \\
\hline & T. cordata & 60 & 19.8 & $\begin{array}{c}17.2-22.4 \\
2.34 \\
\end{array}$ & 22.0 & $\begin{array}{c}16.2-26.5 \\
6.44\end{array}$ & 92 & & \\
\hline \multirow{4}{*}{3} & Q. robur & 70 & 29.5 & $\begin{array}{l}26.2-32.3 \\
\quad 2.45\end{array}$ & 43,2 & $\begin{array}{c}30.2-55.4 \\
8.13\end{array}$ & 330 & \multirow{4}{*}{370.0} & \multirow{4}{*}{0.70} \\
\hline & C. betulus & 70 & 22.7 & $\begin{array}{c}20.0-24.3 ; \\
1.88 \\
\end{array}$ & 29.2 & $\begin{array}{c}25.40-36.7 \\
7.55\end{array}$ & 115 & & \\
\hline & A. platanoides & 65 & 27.1 & $\begin{array}{c}23.2-30.3 ; \\
2.95 \\
\end{array}$ & 30.0 & $\begin{array}{c}25.1-37.2 \\
5.90\end{array}$ & 140 & & \\
\hline & T. cordata & 65 & 18.0 & $\begin{array}{c}17.2-19.5 \\
1.65\end{array}$ & 18.5 & $\begin{array}{c}13.2-23.5 \\
4.78\end{array}$ & 90 & & \\
\hline \multirow{4}{*}{4} & Q. robur & 70 & 29.8 & $\begin{array}{c}25.5-33.2 ; \\
2.45 \\
\end{array}$ & 39.6 & $\begin{array}{c}33.1-56.8 \\
6.33\end{array}$ & 355 & \multirow{4}{*}{392.5} & \multirow{4}{*}{0.85} \\
\hline & C. betulus & 70 & 25.1 & $\begin{array}{c}23.1-27.1 ; \\
2.01\end{array}$ & 32.2 & $\begin{array}{c}27.1-36.6 \\
5.55\end{array}$ & 110 & & \\
\hline & A. platanoides & 60 & 22.9 & $\begin{array}{c}19.7-24.6 \\
2.23\end{array}$ & 28.1 & $\begin{array}{c}20.0-35.3 \\
6.15\end{array}$ & 155 & & \\
\hline & T. cordata & 60 & 23.1 & $\begin{array}{c}20.6-25.2 \\
2.15\end{array}$ & 29.7 & $\begin{array}{c}23.5-31.2 \\
4.12\end{array}$ & 70 & & \\
\hline
\end{tabular}

The weighted average of height largely differed between EPs depending on the intensity of recreational impact. The maximum values of this parameter for Q. robur, Carpinus betulus, Acer platanoides and Tilia cordata were detected in EP4, which were 5.05-11.07\% higher than those at EP1 and EP2. The weighted average of diameters of all species at the studied EPs was also reduced.

The growth reduction in trees was observed. The violation of growth in height and diameter of trees was caused by the high intensity of recreational activity. Correlation relationship between height and diameter in EP3 and EP4 was lower when compared to EP2 and EP1 $\left(\mathrm{R}_{\mathrm{EP} 4}^{2}=0.71 ; \mathrm{R}_{\mathrm{EP} 3}^{2}=0.74 ; \mathrm{R}_{\mathrm{EP} 2}^{2}=0.92 ; \mathrm{R}_{\mathrm{EP1}}^{2}=0.93\right)$. An increase in the distance between the 
trees from 298.9 to $424.1 \mathrm{~cm}$ was recorded (Table 3). The understorey shrub layer was presented at the EP3 and EP4. The understorey consists of Acer tataricum L., Corylus avellana L., Euonymus verrucosa Scop., Sambucus nigra L., Thelycrania sanguinea L. Acer campestre L., Pyrus communis L. and Malus sylvestris Mill.

The value of IVH was the lowest (2.11) in EP4 and the highest (2.22) in EP1 (Table 3). This parameter had the same value in EP3 and EP4. The value of IHH was 0.54, 0.48, 0.50 and 0.41 in EP1-EP4, respectively.

$\mathrm{T} \mathrm{a} \mathrm{b} 1 \mathrm{e}$ 3. Additional parameters of forest vegetation in different experimental plots. Average distance between trees, average density undergrowth, and index of horizontal heterogeneity of vegetation (IHH) and index of vertical heterogeneity of vegetation (IVH) are shown.

\begin{tabular}{|l|c|c|c|c|}
\hline Parameters & EP 1 & EP 2 & EP 3 & EP 4 \\
\hline Average distance between trees (AD) $(\mathrm{cm})$ & $424.1 \pm 21.2$ & $372.5 \pm 18.6$ & $312.5 \pm 15.6$ & $298.9 \pm 14.9$ \\
\hline Average density undergrowth (thousand pieces/ha) & $0.34 \pm 0.02$ & $0.56 \pm 0.03$ & $0.99 \pm 0.05$ & $1.3 \pm 0.07$ \\
\hline IHH & 0.54 & 0.48 & 0.50 & 0.41 \\
\hline IVH & 2.22 & 2.19 & 2.19 & 2.11 \\
\hline
\end{tabular}

\section{Tree health and vitality structure}

The analysis of health conditions revealed a weak stage degree of recreational transformation of biotope in EP1 and an intensive high stage degree of recreational transformation of biotope in EP4 (Fig. 2). The proportion of healthy trees was less than 32.5-58.9\%, weakened trees was $22.7-45.5 \%$, heavily weakened was $16.0-23.7 \%$ and wilting was $0.5-4.5 \%$. Recently dead stands were present only in EP1 (1.5\%) and EP2 (2.8\%). Index of stand state ranged from 1.48 to 2.97 .

Analysis of the vitality of stands revealed a similar trend regarding the distribution of categories of tree state. Number of trees of the high Kraft classes gradually reduced at the ecoprofile. WAKC of wilting $(\mathrm{WAKC}=4.2)$ and seriously weakened (WAKC $=3.8$ ) in EP4 were slightly high compared to the data of other EP (Table 4). Drying of trees was a natural process because of the bio-

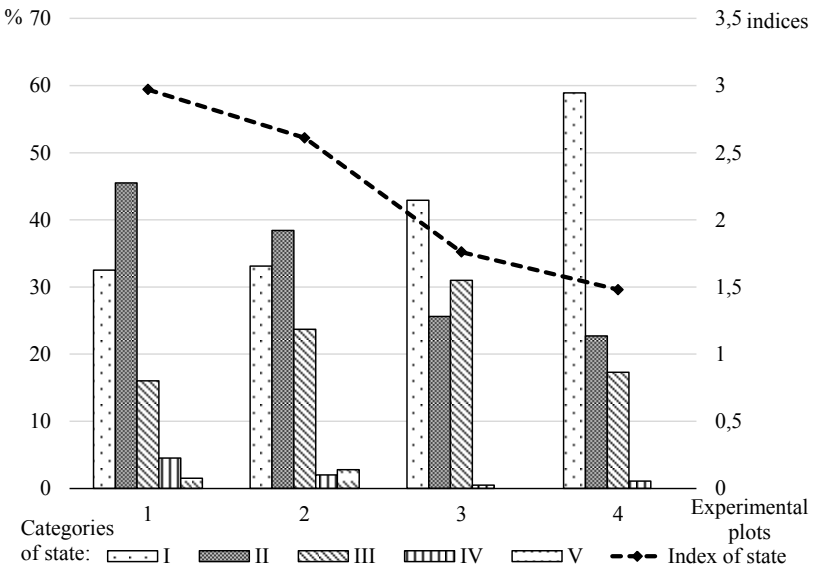

Fig. 2. Health conditions of urban forest stand in the experimental plots. The distribution of stand categories and the relationship between the categories are shown. The share of each stand category is shown in percentages. 
T a b l e 4. Vitality of tree composition in different experimental plots. The weighted average of Kraft class (WAKC) is shown. The share of categories of tree state is shown in percentages.

\begin{tabular}{|l|c|c|c|c|c|c|c|c|c|c|}
\hline \multirow{2}{*}{ No. EP } & \multicolumn{9}{|c|}{ Categories of tree state } \\
\cline { 2 - 16 } & \multicolumn{2}{|c|}{ I } & \multicolumn{2}{|c|}{ II } & \multicolumn{2}{c|}{ III } & \multicolumn{2}{|c|}{ IV } & \multicolumn{2}{c|}{ V } \\
\cline { 2 - 15 } & WAKC & \% & WAKC & \% & WAKC & \% & WAKC & \% & WAKC & \% \\
\hline 1 & 1.3 & 32.5 & 1.9 & 45.5 & 2.1 & 16.0 & 4.5 & 4.5 & 5.5 & 1.5 \\
\hline 2 & 1.0 & 33.1 & 2.7 & 38.4 & 3.8 & 23.7 & 4.5 & 2.0 & 5.5 & 2.8 \\
\hline 3 & 1.1 & 42.9 & 2.3 & 25.6 & 3.9 & 31.0 & 4.4 & 0.5 & 0 & 0 \\
\hline 4 & 1.0 & 58.9 & 2.1 & 22.7 & 3.8 & 17.3 & 4.2 & 1.1 & 0 & 0 \\
\hline
\end{tabular}

logical characteristics of species in this EP. Trees of II and III classes Kraft began to wither in EP2 and EP3. The values for WAKC of weakened and seriously weakened were 2.3 and 3.9, respectively, in EP3 and 2.7 and 3.8, respectively, in EP2. Such a distribution of trees in Kraft classes of stands is caused by the recreational transformation of urban forest.

\section{Herbaceous and soil surface layers}

The floristic list of the all EPs comprised 78 grass species belonging to 72 genera, 19 families. It included species of Liliopsida and Magnoliopsida. Asteraceae (18 species, 24.3\%) was the most represented family. Poaceae (11 species, 14.1\%), Lamiaceae (10 species, $12.8 \%$ ) and Fabaceae (9 species, 11.5\%) had almost the same distribution of species. These were followed by Ranunculaceae (5 species, 6.4\%), Polygonaceae (4 species, 5.1\%), Caryophyllaceae (3 species, 3.8\%) and Scorphulariaceae (3 species, 3.8\%). The remaining families had less than three species. Four families were represented by two species. Seven families were represented by one species.

The herbaceous cover of EP1 is rather poor; the projected cover was 55.2\%. Altogether 32 species were found at EP1. About $18.9 \%$ of species were ruderal and adventitious herbaceous species (Ambrosia artemisiifolia L., Chelidonium majus L., Convolvulus arvensis L., Malva sylvestris L., Sonchus arvensis L., Stenactis annua L., Taraxacum officinale L., Polygonum aviculare L., Rumex confertus L. and others). The soil surface was in IV stage of degradation. The total projected cover of herbaceous storey at the EP2 was 61.5\% (41 species). About $9.8 \%$ of species were ruderal or adventitious. The soil surface was in III stage of degradation. The total projected cover of herbaceous storey at the EP3 was higher than that at the EP2 $(85.5 \%$; 45 species). The forest species (Anemone nemorosa L., Asarum europaeum L., Dryopteris filix-mas (L.) Schott., Mercurialis perennis L., Geranium robertianum L., Galanthus nivalis L., Polygonatum multiflorum (L.) All. and others) were dominated. The soil surface was in II stage of degradation. The most florist saturation (48 species) was detected at the EP4. The projected cover was $93.5 \%$. Only Dactylis glomerata L. as the representative ruderal species was found at this EP. The soil surface was in I stage of degradation.

The adventive index was $18.9 \%$ (EP1), 9.8\% (EP2), 8.8\% (EP3) and $2.1 \%$ (EP4) at the ecoprofile.

In accordance with the results, the stages of recreational transformation of EP were as follows: EP1, IV; EP2, III; EP3, II; EP1, I. 
A total of 43 bird species belonging to 9 orders were observed during the study at the ecoprofile (Appendix 1). Average density of nesting birds was $2.2 \pm 0.56 \mathrm{pairs} / \mathrm{km}$. The highest number of species was detected at the EP4 (38 species from 9 orders including 34 nesting species). Average density of birds was $2.0 \pm 0.53$ pairs $/ \mathrm{km}$ in EP1. The number of species that used the territory of EP for foraging was approximately the same in EP2 and EP3. The number of nesting species was significantly different. EP3 consists of 17 species from 2 orders; all species were nesting birds. Average density of nesting birds was $1.8 \pm 0.50$ pairs $/ \mathrm{km}$. EP2 consists of 19 species from 3 orders; 9 species from 3 orders were nesting birds. The average density of nesting birds in this EP was $3.1 \pm 0.63$ pairs $/ \mathrm{km}$. The number of species was the least (nine species from three orders) for EP4 with weak stage of recreational transformation of biotope. The adult individuals together with the young individuals of birds were moved between EP1 and EP3.

Dominant species of birds by numerosity in communities was duplicated in all EPs. The following were the most common species in the forest biotopes of the region: Parus major, Fringilla coelebs, Erithacus rubecula, Turdus merula and Sitta europaea.

\section{Ecological composition of nesting birds}

In general, avifauna of all EPs was distributed to the ecological groups: 33 species (76.74\%) were woody nesters (19 species (44.18\%) are tree hollow nesters), 5 species (11.63\%) were ground nesters, 3 species $(6.98 \%)$ were cavities nesters and 2 species $(4.65 \%)$ were water nesters.

All recorded birds in EP1 were foraging species and didn't have nests. Only woody nesters were nesting species (one nesting guild). Three nesting guilds were present in EP3 and EP4. Nine species in EP3 were woody nesters: four species were tree hollow nesters, two species were ground nesters (Phylloscopus collybita, Luscinia luscinia) and one species was cavities nester (Erithacus rubecula). Birds of these species had well-sheltered nest. These species were recorded on feeding and vocalisation. The signs of breeding behaviour were observed. Twenty-six species in EP4 were woody nesters: 14 species were tree hollow nesters, 5 species were ground nesters and 3 species were cavities nesters. Share of bird's tree canopies nesters in EP3 was higher when compared to the data of EP2. Nesting by type of cavities nesters was established not only for E. rubecula but also for Motacilla alba and Alcedo atthis, which nested in erosion outcrops of geological rocks of a forest ravines.

A decrease in the number of breeding species with an increase in their average nesting density was revealed in bird communities of more recreationally transformed EP1-EP3 compared to the bird communities of EP4. The number of species and their density was also reduced to the complete cessation of nesting. It should be noted that almost half of the species composition of woody nesters occurred in bird's tree canopies nesters in EP4. Their abundance was associated with the topical activity of woodpeckers.

Avifauna of the Forest-Steppe zone of Ukraine was characterized by six species of woodpeckers. All species were noted at the studied plots: Picus canus, Dryocopus martius, Dendrocopos major, D. syriacus, D. medius (Leiopicus medius or Dendropicos medius), D. minor 


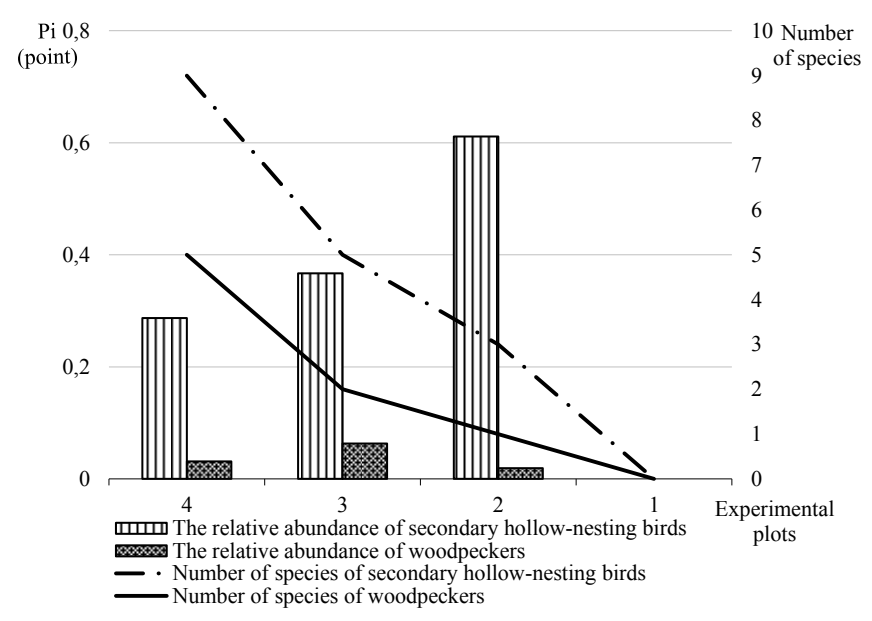

Fig. 3. The ratio of woodpeckers to the secondary tree hollow nesters of nesting bird communities. The relative abundance and number of species are shown.
(Dryobates minor) (Sangster et al., 2016). Woodpeckers were nesting species at all EPs except EP1. Woodpeckers were feeding only at EP1. These birds afforded nesting stations for secondary tree hollow nesters. All nests of the tree hollow nesters were sheltered and protected. Sturnus vulgaris, Parus major and Sitta europaea were feeding species. These birds were not breeding species because of the absence of nesting stations (hollows).

Our results show that

the increase in the number and abundance of nesting species of woodpeckers caused increase in the number and abundance of secondary tree hollow nesters (Fig. 3). This can be explained by the absence of nesting species, which were not adapted to recreational transformation. In this study: Tringa ochropus, Alcedo atthis, Lullula arborea, Anthus trivialis, Motacilla alba, Troglodytes troglodytes, Sylvia atricapilla, Phylloscopus sibilatrix, Turdus pilaris, Aegithalos caudatus (Appendix 1). Low abundance of woodpeckers in EP2 was caused by nesting of only Dendrocopos syriacus. This is a synanthropic adventive species of the fauna of Ukraine. D. syriacus was absent in EP3 and EP4. Native species of woodpeckers were absent at EP2. Motacilla alba and Turdus pilaris were absent too. These species are hemysynanthropes in the studied area.

\section{Ecological composition of feeding birds}

Share of species of birds those forming synanthropic subpopulations such as Parus major, Fringilla coelebs, Erithacus rubecula, Turdus merula and Sitta europaea were increased on the recreational transformation gradient in communities of feeding birds. The distribution of species was as follows: 23 hemysynanthropic species (60.53\%) in EP4,14 hemysynanthropic species $(82.35 \%)$ in EP3, 17 hemysynanthropic species $(89.47 \%)$ in EP2 and 9 hemysynanthropic species (100\%) in EP1. The abundance of hemysynanthropic species was increased too: 0.903 (EP4), 0.939 (EP3), 0.974 (EP2) and 1.0 (EP1).

\section{Trophic composition of feeding birds}

The birds with mixed type of feeding ( 21 species, $48.83 \%$ ) and insectivorous birds ( 16 species, $37.21 \%$ ) were dominated at the ecoprofile. In EP1, seven species with mixed type of feeding, 
one granivorous species (Columba palumbus) and one insectivorous species (Acrocephalus arundinaceus) were founded. Distribution by trophic groups of birds in EP2 was similar to that of EP1. In EP2, 10 species with mixed type of feeding, 8 insectivorous species and 1 granivorous species were found. The birds with mixed type of feeding and insectivorous birds were distributed in the same proportion (eight species) in EP3. Garrulus glandarius (pantophagous bird) was found in EP3. The same distribution between the two types of feeding was typical for EP4: 16 species with mixed type of feeding and insectivorous birds. In this EP, two species of predatory birds and one granivorous species were recorded too. Ardea cinerea and Alcedo atthis (fish-eating birds) were recorded in EP4. These species had nests far away from ecoprofile. Birds were fed on the ground and on trees at all EPs.

\section{Assessment of plant and birds biodiversity. Diversity indices}

Indices of diversity of phytocoenoses and avifauna indicate qualitatively anthropogenic changes in ecological conditions in urban forest ecosystem. Assessment of plant diversity showed that maximal species richness indices was observed in EP4 (Fig. 4). The computed Shannon, Menchinick, Margalef and Simpson indices for EP2 and EP3 were almost the same. The lowest values of these indexes were in EP1 where adventitious and ruderal species had the highest share of phytocoenoses. Ecological conditions of EP1 were favourable only for dominate adventitious and ruderal species.

We analysed the bird's communities that used the territory of EP for foraging because birds didn't nest in EP1. All indices of diversity of avifauna showed the highest values in EP4, but the tendency of these changes was different. The largest fluctuation of amplitude values was observed for Margalef indices. The most stable were the values of Simpson and Menchinick indices. Comparative evaluation of indices of diversity of phytocoenoses and avifauna in urban forest ecosystem on recreational transformation gradient showed that human activities equally lead to the violation of composition of plants and birds communities. At the same time, the changes in the values of Simpson and Shannon indices for plant com-

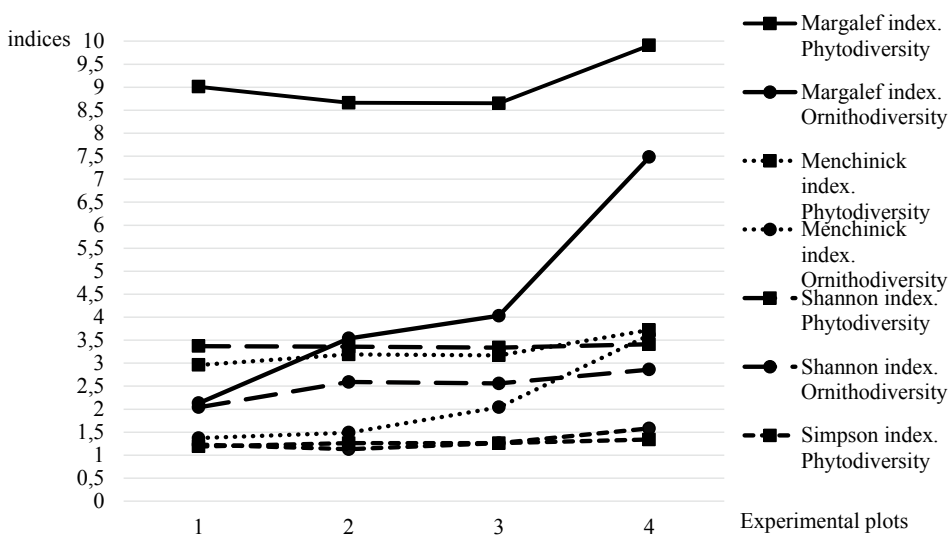

Fig. 4. The comparison of the trends of species diversity indices of plants and birds communities in the experimental plots. The Shannon and Simpson indexes show a similar tendency. 


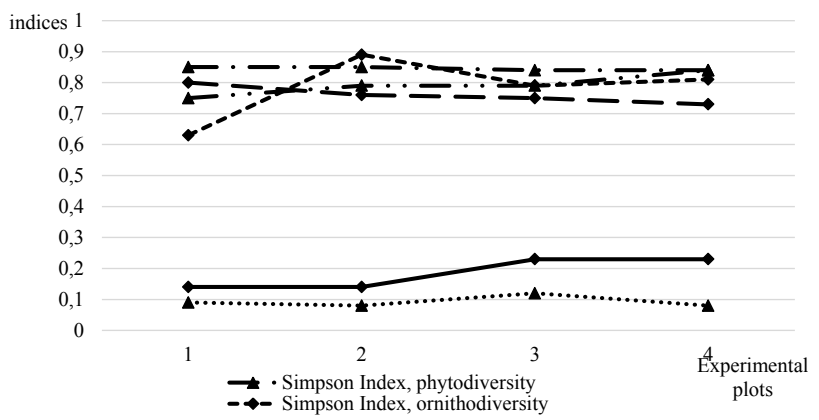

Fig. 5. The comparison of the trends of species dominance indices of plants and birds communities in the experimental plots.

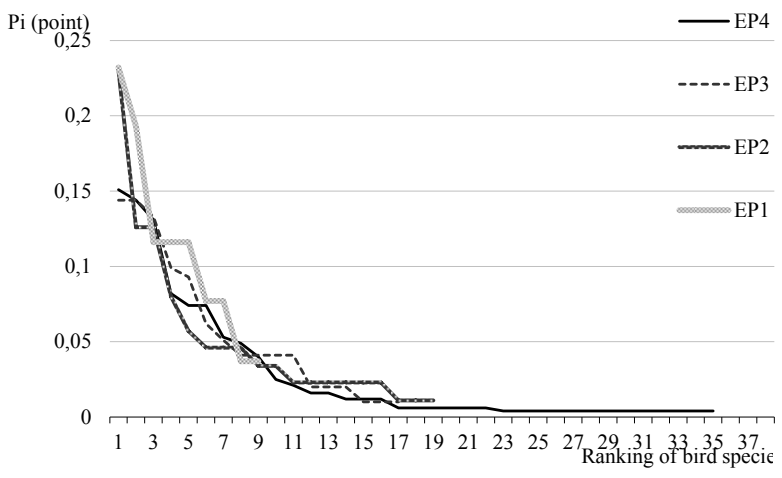

(a)

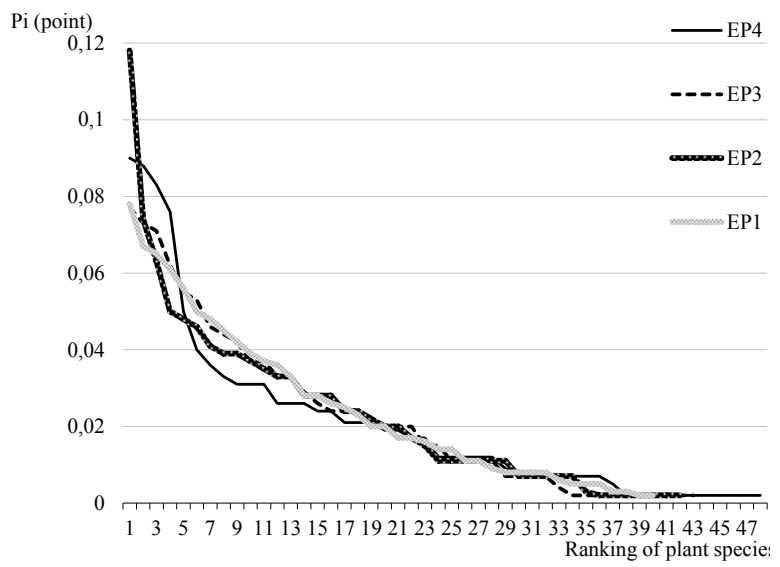

(b)

Fig. 6. Evenness of species in (a) plant communities and (b) feeding birds in experimental plots. Evenness indices of vegetation layer demonstrate balanced equitability of plant. Evenness indices of bird species point to the extremely negative state of avifauna of recreational transformed EP. munities and avifauna were almost synchronous. Values of Margalef and Menchinick indices of avifauna described the appropriate changes more clearly.

\section{Dominance indices}

Assessment of dominance indices showed that the level of dominance for plants and birds communities was high in EP1-EP3 and the lowest values were in EP4 (Fig. 5). This indicated that the ecological conditions were favourable for some species of plants (D. glomerata, Parus major, Sonchus arvensis, Stenactis annua, Lamium purpureum and others) and birds (Columba palumbus, Dendrocopos major, D. syriacus, Sturnus vulgaris and others) on intensive recreational transformation territory (EP1). Remaining species of plants and birds were more depressed.

Almost 50\% of the species composition of birds that marked in studied area avoided to attend the intensive transformed EP1 for feeding and nested exclusively on EP2-EP4. The computed McIntosh index showed the most stable values of dominance, which were gradually decreasing from EP1 to EP4. The com- 
puted Berger-Parker index changed in the opposite direction. The computed Simpson index was the highest in EP3.

\section{Evenness indices}

Evenness indices of vegetation layer demonstrated balanced equitability of plant at the ecoprofile (Fig. 6). Ranked curves showed the worst state of species dominance for the phytocommunity in EP2. The greatest number of species and transfer from the most numerous species to common and limited species were founded in EP4. Evenness of bird's species pointed to the extremely negative state of avifauna of recreationally transformed EP. Ranked curves showed the dominance of two and four species in EP1 and EP2, respectively (Fig. 6). The limited species were absent in EP1-EP3. Moreover, our results show that a smallest number of birds caused the density of limited species in these EP. This indicates that the birds used the EPs more for feeding than for nesting. Balanced birds community with a sufficient number of species and evenness of these species were found only in EP4. The relative abundance of all species was from 0.005 to 0.138 .

Pielou's indices of evenness for plant community were 1.95 (EP1), 1.99 (EP2), 2.00 (EP3) and 1.97 (EP4). McIntosh indices of evenness for plant community were 0.92 (EP1), 0.92 (EP2), 0.93 (EP3) and 0.91 (EP4). Pielou's indices of evenness for birds community were 2.14 (EP1), 2.00 (EP2), 2.02 (EP3) and 1.85 (EP4). McIntosh indices of evenness for birds community were 0.93 (EP1), 0.87 (EP2), 0.90 (EP3) and 0.86 (EP4).

\section{Assessment of other indicators of communities}

The most number of tree canopies nesters and ground nesters was recorded in EP4, where the highest developed classes of trees (I-II) and the lowest state index were found (Fig. 7). The appropriate species were not registered in EP1, where the lowest developed classes of trees grew.

The increase in the share of species of synanthropic subpopulations and the relative abundance of hemysynanthropes in the breeding bird's community along the gradient of recreational urban

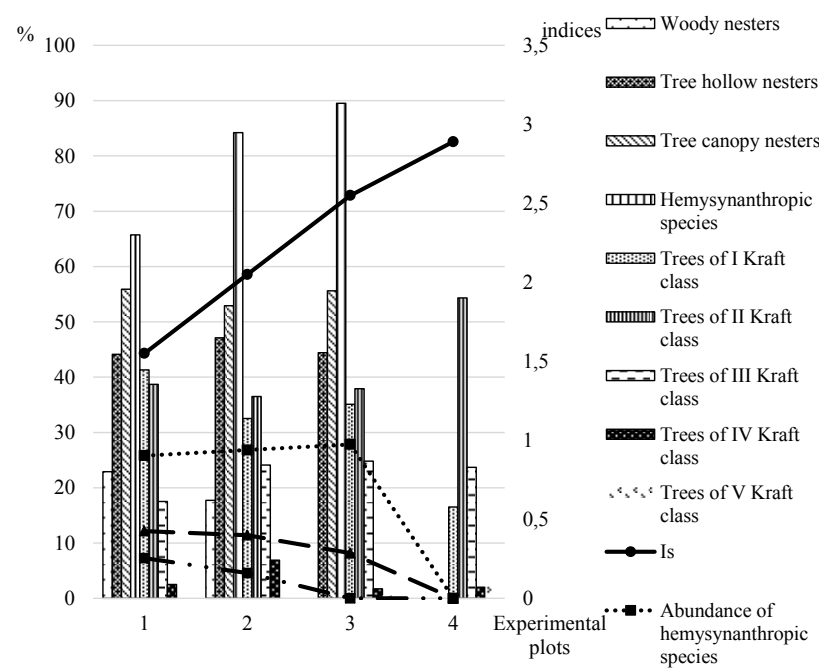

Fig. 7. The share of various ecological groups of birds and vitality and health compositions of trees in the experimental plots. 
transformation showed a significant human impact on avifauna. Species of birds forming obligatory synanthropic populations were absent. Vulnerable species of 2 and 3 of the Berne Convention categories were nested in EP4 (Appendix 1). The presence of species such as Tringa ochropus, Alcedo atthis, Dryocopus martius, Anthus trivialis, Hippolais icterina and Ficedula parva in the fauna list is an indicator of sustainable development of urban forest ecosystem for Forest-steppe zone of Ukraine. The habitat of Dryocopus martius was typical for mature European forests (Felton et al., 2016).

\section{Discussion}

The relationships between bird communities and vegetation composition in the urban forest ecosystem have long attracted the attention of scientists (Erdelen, 1984; Sanchez et al., 2012). The analysis of scientific literature showed that the changes in the species composition of forest trees can influence not only the habitat selection (Gabbe et al., 2002) but also the community structure of birds (Rodewald, Abrams, 2002). Tree species richness in a forest can have positive effects on bird species nesting on the ground and also on the overall diversity of birds from the studied forests (Salek et al., 2010).

An important factor affecting the number of birds is the degree of transformation of grassy and shrubby layers for ground birds (Camprodon, Brotons, 2006; Heyman, 2010; Shupova, 2017). Moreover, our results show that a stage of recreational transformation causes a marked decrease in the abundance of ground birds in all EP. The share of tree canopies nesters decreases from 22.9 to $0 \%$, and their relative abundance in the community decreases from 0.227 to 0 . In order to maintain the diversity of birds, it is necessary to have a shrub layer, snags and stumps (Assadi et al., 2015). In general, the heterogeneity of the environment contributes to an increase in the alpha diversity of communities (Katsimanis et al., 2006; Shupova, Chaplygina, 2016).

The result of direct human impact on birds, realised through the anxiety factor, is most rapid, causing the disappearance of vulnerable species. Birds return to the nesting stations when the disturbance factor is eliminated or reduced to an acceptable level (Martin, Joron, 2003; Gill, 2006; Brockerhoff et al., 2008; Bykov, 2011; Graham et al., 2014). The authors indicate that the recreational transformation of urban forest causes changes in the species composition of nesting birds, the number of individual species, the abundance of guilds and the structure of nesting bird communities. If the biotope transformation exceeds the threshold of adaptability of a certain species, it leaves the urban forest forever. Limited and specialised species reducing locality under conditions of transformation of natural ecosystems eliminate from the communities of nesting birds (Shupova, 2001; Chaplygina et al., 2016; Shupova, Chaplygina, 2016).

Secondary tree hollow nesters that nest in ready-made tree hollows are less common with an insufficient number of woodpeckers and hollows (Angelstam, Mikusinski, 1994; Carlson et al., 1998; Mikusinski et al., 2001; Virkkala, 2006; Robles et al., 2011). The existence of such a relationship has been confirmed in our study. The development of tree hollows is also aided by the excavation activities of woodpecker species, which, in addition to many other vertebrate species, use such hollows for breeding (Angelstam, Mikusinski, 1994; Carlson et 
al., 1998). Because of the ability of woodpeckers to provide nesting sites for secondary-cavity nesters, they are often considered key-stone environmental engineers (Virkkala, 2006) and their presence can likewise reflect an increased richness of other forest birds (Robles et al., 2012).

Decrease in the abundance of woody and an increase in the share of nesters tree canopies nesters were recorded on gradient of recreational transformation. Stenotopic species disappear from the bird community. A resembling phenomenon for a similar type of forest is associated with the simplicity and homogeneity of the habitat of birds (Felton et al., 2016). Plantations of native tree species can support bird communities comparable to communities of natural forests in regions that do not have singly specialised forest birds species (Graham et al., 2014). The results of other surveys indicated that mature production stands possessed a bird community partially overlapping in species composition, and comparable in species richness to that found within the natural stands. Many of the mature production stands visited contained threatened or near threatened bird species, including the near threatened black woodpecker (Felton et al., 2016).

Insectivorous birds have a shortage of food resources with insufficient development of the grass layer, which is important as a resource for invertebrates (Pereira et al., 2014; Bergner et al., 2015). On the other side, fragmentation and the ecotone effect increase the availability of food to bird (Batary et al., 2014). An increase in the density of feeding birds on recreationally transformed areas relates to human activities, and some types of feed objects are more accessible.

Our studies showed a slight increase in the number of birds with mixed type of feeding because of a decrease in the share of insectivorous birds in communities along the gradient of the recreational transformation of urban forest. Our results confirmed the loss of most species that specialised in collecting food on ground and grass layers (Appendix 1). Assessment of correlations between parameters of plant communities and birds communities confirmed significant relationship between the index of vertical heterogeneity and the number of bird species, nesting density $(\mathrm{r}=0.76, \mathrm{p}<0.01 ; \mathrm{r}=0.72, \mathrm{p}<0.01)$ (Table 5). A relationship between index of vertical heterogeneity and the Margalef index of diversity $(r=0.74, p<0.01)$ was slightly weaker. Our data showed the relationship between storied vertical composition of forest and species diversity of birds. A relationship between IHH and other parameters was not confirmed in our results.

Correlation between diversity indices of plants (Margalef, Menchinick) and the number of bird species was confirmed. Correlation between plants and birds diversity indices, in particular Margalef indices $(\mathrm{r}=0.79, \mathrm{p}<0.01)$, Menchinick indices $(\mathrm{r}=0.96, \mathrm{p}<0.005)$, Shannon indices $(\mathrm{r}=0.75, \mathrm{p}<0.01)$, Simpson indices $(\mathrm{r}=0.81, \mathrm{p}<0.01)$ and others, was confirmed too. These data suggest a relationship between bird species diversity and floristic richness of forest. The results of our study are consistent with the data of other authors. Relationship between the vertical composition of the forest, the vertical distribution of leaves and bird species diversity was confirmed (MacArthur R., MacArthur J., 1961).

It was proven that the forests with complex composition and floristic richness have a high diversity of birds' communities (Easton, Martin, 2002; Poulsen, 2002; Westphal et al., 2003; Wilson et al., 2006). Results of other studies showed that change in the number of bird species and the formation of guilds of birds depends on the forest type and vertical hetero- 
T a b l e 5. Correlation matrix of diversity indices of plant communities and bird communities. Indices of horizontal heterogeneity of vegetation and vertical heterogeneity of vegetation are also shown.

\begin{tabular}{|c|c|c|c|c|c|c|c|c|c|c|c|c|c|c|}
\hline Indices & $\mathbf{N}_{1}$ & $P_{1}$ & $\mathrm{DMg}_{1}$ & $\mathrm{DMn}_{1}$ & $\mathrm{H}_{1}$ & $\mathrm{Us}_{1}$ & $\mathrm{~N}_{2}$ & $\mathbf{P}_{2}$ & $\mathrm{DMg}_{2}$ & $\mathrm{DMn}_{2}$ & $\mathbf{H}_{2}$ & $\mathrm{Us}_{2}$ & IHH & IVH \\
\hline $\mathrm{N}_{1}$ & - & - & - & - & - & - & - & - & - & - & - & - & - & - \\
\hline$P_{1}$ & 0.64 & - & - & - & - & - & - & - & - & - & - & - & - & - \\
\hline $\mathrm{DMg}_{1}$ & 0.99 & 0.39 & - & - & - & - & - & - & - & - & - & & - & - \\
\hline $\mathrm{DMn}_{1}$ & 0.97 & 0.44 & 0.97 & - & - & - & - & - & - & - & - & - & - & - \\
\hline $\mathbf{H}_{1}$ & 0.88 & 0.63 & 0.88 & 0.77 & - & - & - & - & - & - & - & - & - & - \\
\hline $\mathrm{Us}_{1}$ & 0.88 & 0.07 & 0.89 & 0.96 & 0.57 & - & - & - & - & - & - & - & - & - \\
\hline $\mathrm{N}_{2}$ & 0.37 & -0.59 & 0.37 & -0.26 & -0.08 & 0.71 & - & - & - & - & - & - & - & - \\
\hline $\mathbf{P}_{2}$ & -0.75 & -0.15 & -0.74 & -0.61 & -0.97 & -0.38 & 0.32 & - & - & - & - & - & - & - \\
\hline $\mathrm{DMg}_{2}$ & 0.79 & -0.25 & 0.79 & 0.86 & 0.44 & 0.94 & 0.85 & -0.21 & - & - & - & - & - & - \\
\hline $\mathrm{DMn}_{2}$ & 0.78 & 0.21 & 0.89 & 0.96 & 0.77 & 0.87 & 0.4 & -0.73 & 0.82 & - & - & - & & - \\
\hline $\mathrm{H}_{2}$ & 0.61 & -0.45 & 0.71 & 0.75 & 0.38 & 0.81 & 0.84 & -0.15 & 0.96 & 0.76 & - & - & - & - \\
\hline $\mathrm{Us}_{2}$ & 0.67 & 0.39 & 0.41 & 0.9 & 0.86 & 0.75 & 0.17 & -0.87 & 0.66 & 0.97 & 0.55 & - & - & - \\
\hline IHH & -0.84 & 0.41 & -0.96 & -0.89 & -0.92 & -0.77 & -0.28 & 0.8 & -0.73 & -0.9 & -0.68 & -0.98 & - & - \\
\hline IVH & 0.76 & 0.72 & 0.74 & -0.96 & -0.86 & -0.88 & -0.42 & 0.72 & -0.83 & -0.99 & -0.73 & -0.96 & 0.97 & - \\
\hline
\end{tabular}

Notes: $\mathrm{N}$ - number of species P - density of species; DMg - Margalef index; DMn - Menchinick index; $\mathrm{H}$ - Shannon index; $\mathrm{U}_{\mathrm{s}}$ - Simpson index; IHH - index of horizontal heterogeneity of vegetation; IVH - index of vertical heterogeneity of vegetation; 1 - Data for plant communities; 2 - Data for bird communities.

geneity: the number of birds decreased with decreasing vertical heterogeneity (Wen et al., 2002). The dependence of species and trophic composition of birds and the complexity and storeyed composition of forest was shown in the study (Sekercioglu, 2002). The author noted the direct relationship between the composition of ecological groups of birds and the forestry practices impact. Our results showed the dependence of compositions of plant and birds communities on the intensity of recreational transformation of urban forest. Indices of plant communities and bird's communities varied depending on the transformation of the environment. These results showed that species composition associated with floristic diversity. The studies of other authors confirmed this (Roth, 1976; Lewis, Starzomski, 2015).

The development of forest canopy affects, to a greater extent, the species richness of birds and, to a lesser extent, their overall density (Graham et al., 2014). Other authors showed that reduction of crown density leads to the dominance of tree canopies nesters (Thiollay, 1997; Dranzoa, 1998). Our results confirmed that changing crown density from 0.85 to 0.50 and reducing stand basal area from 392.5 to $298.1 \mathrm{~m}^{2} \mathrm{ha}^{-1}$ caused decrease in the species composition of birds and violation of ecological groups of nesting birds. Synantropisation was inherent to communities of nesting birds. The threat of the availability of nests for people and predators in transformed areas was the main cause of displacement of species.

The dependence of the diversity of bird communities on the heterogeneity of the stand and the mosaic of habitats was repeatedly emphasised in other studies (Tews et al., 2004; Giltena et al., 2007; Moreno-Rueda, Pizzaro, 2009; Stefanova, Salek, 2014; Domokos E., Domokos J., 2016). The authors suggested that the transformed environment could reduce species abundance because of a decrease in the populations of some species. Limited and 
rare species was eliminated from the bird communities of many regions (Issoti et al., 2014). Loss of rare and limited species can lead to degradation of ecosystem functions (Seymour et al., 2015).

\section{Acknowledgements}

This work was supported by the National University of Life and Environmental Sciences of Ukraine, Grant No. 0117 U002647.

\section{References}

Angelstam, P. \& Mikusinski G. (1994). Woodpecker assemblages in natural and managed boreal and hemiboreal forest - a review. Ann. Zool. Fenn., 31(1), 157-172.

Anuchin, N. (1977). Forest taxation (in Russian). Moscow: Nauka.

Assadi, S.B., Kaboli, M., Etemad, V., Khanaposhtani, M.G. \& Tohidifar M. (2015). Habitat selection of cavitynesting birds in the Hyrcanian deciduous forests of northern Iran. Ecol. Res., 30(5), 889-897. DOI: 10.1007/ s11284-015-1293-z.

Atemasova, T. (2015). A structure of bird communities at forests park zone of Kharkov (Ukraine). Belgorod State University Scientific Bulletin, Natural Sciences, 30(3), 74-81.

Barbarich, A. (1977). Geobotanical subdivision of Ukraine (in Ukrainian). Kyiv: Science.

Batary, P., Fronczek, S., Normann, C., Scherber, C. \& Tscharntke T. (2014). How do edge effect and tree species diversity change bird diversity and avian nest survival in Germany's largest deciduous forest? For. Ecol. Manag., 319, 44-50. DOI: 10.1016/j.foreco.2014.02.004.

Bergner, A., Avci, M., Eryiğit, H., Jansson, N., Niklasson, M., Westerberg, L. \& Milberg P. (2015). Influences of forest type and habitat structure on bird assemblages of oak (Quercus spp.) and pine (Pinus spp.) stands in southwestern Turkey. For. Ecol. Manag., 336, 137-147. DOI: 10.1016/j.foreco.2014.10.025.

Bibby, C., Burgess, N., Hill, D. \& Mustoe S. (2000). Bird census techniques. London: Academic Press.

Blinkova, O. (2014). Synphytoindication recreational ecological changes conditions of plant formation in protected areas the Borzhava, Zakarpatska lowland. Odesa National University Herald Biology, 19(2), 21-33.

Blondel, J. \& Cuvillier R. (1977). Une methode simple et rapide pour decrier les habitats doiseaux: le stratiscope. Oikos, 29, 326-331. DOI: 10.2307/3543622.

Bragin, E. \& Bragina T. (2014). Modern composition and structure of the avifauna Naurzum reserve. Journal of Omsk University, 2, 98-101.

Braun-Blanquet, J. (1964). Pflanzensoziologie, grundzüge der vegetationskunde. New York: Springer.

Brockerhoff, E.G., Jactel, H., Parrotta, J.A., Quine, Ch.P. \& Sayer J. (2008). Plantation forests and biodiversity: oxymoron or opportunity? Biodivers. Conserv., 17(5), 925-951. DOI: 10.1007/s10531-008-9380-x.

Burda, R. (2006). Trends change of phytodiversity in agricultural landscapes of Ukraine. Scientific Bulletin of National Agricultural University of Ukraine, 93, 1-15.

Bykov, E. (2011). Recreational transformation of deciduous forests and the species structure of the breeding bird fauna. Izv. Penz. Gos. Pedagog. Univ. im V.G. Belinskogo, 25, 170-175.

Camprodon, J. \& Brotons L. (2006). Effects of undergrowth clearing on the bird communities of the Northwestern Mediterranean Coppice Holm oak forests. For. Ecol. Manag., 221(1-3), 72-82. DOI: 10.1016/j. foreco.2005.10.044.

Carlson, A., Sandstrom, U. \& Olsson K. (1998). Availability and use of natural tree holes by cavity nesting birds in a Swedish deciduous forest. Ardea, 86(1), 109-119.

Catsadorakis, G. (1997). Breeding birds from reed beds to alpine meadows. Hydrobiologia, 351, 143-155. DOI: 10.1023/A:1003080911744.

Chaplygina, A., Shupova, T. \& Nadtochiy A. (2016). The avifauna of the National Nature Park «Homilshanski Lisy». Visn. Dnipropetr Univ. Ser. Biol. Ecol., 24(1), 124-133.

Conner, R.N. \& Dickson J.G. (1997). Relationships between bird communities and forest age, structure, species composition and fragmentation in the west gulf coastal plain. Texas J. Sci., 49(Suppl. 3), 123-138.

Didukh, Y. (1994). Phytoindication of ecological factors (in Russian). Kyiv: Naukova Dumka. 
Domokos, E. \& Domokos J. (2016). Bird communities of different woody vegetation types from the Niraj Valley, Romania. Turk. J. Zool., 40, 734-742. DOI: 10.3906/zoo-1510-64.

Dranzoa, Ch. (1998). The avifauna 23 years after logging in Kibale National Park, Uganda. Biodivers. Conserv., 7, 777-797. DOI: 10.1023/A:1008892419940.

Easton, W.E. \& Martin K. (2002). Effects of thinning and herbicide treatments on nest- site selection by songbirds in young, managed forests. Auk, 119, 685-694. DOI: 10.1642/0004-8038(2002)119[0685:EOTAHT]2.0.CO;2.

Erdelen, M. (1984). Bird communities and vegetation structure: I. Correlations and comparisons of simple and diversity indices. Oecologia, 61, 277-284. DOI: 10.1007/BF00396773.

Erofeev, I. (1960). Vinnica (in Russian). Moscow: Education.

Etterson, M.A., Etterson, J.R. \& Cuthbert F.J. (2007). A robust new method for analyzing community change and an example using 83 years of avian response to forest succession. Biol. Conserv., 138(3-4), 381-389. DOI: 10.1016/j.biocon.2007.05.003.

Felton, A., Hedwall, P.O., Lindbladh, M., Nyberg, T., Felton, A.M., Holmström, E., Wallin, I., Löf, M. \& Brunet J. (2016). The biodiversity contribution of wood plantations: Contrasting the bird communities of Sweden's protected and production oak forests. For. Ecol. Manag., 365(1), 51-60. DOI: 10.1016/j.foreco.2016.01.030.

Fischer, J., Lindenmayer, D.B., Blomberg, S.P., Montague-Drake, R., Felton, A. \& Stein J.A. (2007). Functional richness and relative resilience of bird communities in regions with different land use intensities. Ecosystems, 10(6), 964-974. DOI: 10.1007/s10021-007-9071-6.

Fuller, R.J. \& Moreton B.D. (1987). Breeding bird population of Kentish sweet chestnut (Castanea sativa) coppice in relation to age and structure of the coppice. J. Appl. Ecol., 24(1), 13-27. DOI: 10.2307/2403784.

Gabbe, A.P., Robinson, S.K. \& Brawn J.D. (2002). Tree-species preferences of foraging insectivorous birds: implications for floodplain forest restoration. Conserv. Biol., 16(2), 462-470. DOI: 10.1046/j.1523-1739.2002.00460.x.

Gardner, T., Barlow, J., Araujo, I., Avila-Pires, T., Bonaldo, A., Costa, J., Esposito, M., Ferreira,L., Hawes, J., Hernandez, M., Hoogmoed, M., Leite, R., Lo-Man-Hung, N., Malcolm, J., Martins, M., Mestre, L., Miranda-Santos, R., Overal, W., Parry, L., Peters, S., Ribeiro-Junior, M., da Silva, M. \& Peres C. (2008). The cost-effectiveness of biodiversity surveys in tropical forests. Ecol. Lett., 11(2), 139-150. DOI: 10.1111/j.1461-0248.2007.01133.x.

Gill, R. (2006). Influence of large herbivores on tree recruitment and forest dynamics. In K. Danell, R. Bergstrom, P. Duncan \& J. Pastor (Eds.), Large herbivore ecology, ecosystem dynamics and conservation. Cambridge: Cambridge Scientific Press.

Giltena, A., Saura, S. \& Brotons L. (2007). Effects of forest composition and structure on bird species richness in a Mediterranean context: implications for forest ecosystem management. For. Ecol. Manag., 242(2-3), 470-476. DOI: $10.1016 /$ j.foreco.2007.01.080.

Graham, C., Wilson, M., Gittings, T., Kelly, T., Irwin, S., Sweeney, O. \& O’Halloran J. (2014). Factors affecting the bird diversity of planted and semi-natural oak forests in Ireland. Bird Study, 61, 309-320. DOI: 10.1080/00063657.2014.927415.

Heyman, E. (2010). Clearance of understory in urban woodlands: assessing impact on bird abundance and diversity. For. Ecol. Manag. 260(1), 125-131. DOI: 10.1016/j.foreco.2010.04.011.

Hiby, L. \& Krishna M. (2001). Line transect sampling from a curving path. Biometrics, 57(3), 727-731. DOI: 10.1111/j.0006-341X.2001.00727.x.

Hinsley, S., Bellamy, P., Newton, I. \& Sparks T. (1995). Habitat and landscape factors influencing the presence of individual breeding bird species in woodland fragments. J. Avian Biol., 26, 94-104. DOI: 10.2307/3677057

International Code of Nomenclature for algae, fungi and plants (Melbourne Code) adopted by the Eighteenth International Botanical Congress (Internet) (2012). Melbourne: International Association for Plant Taxonomy. (cited 2016 Dec 5). Available from: http://www.iapt-taxon.org/nomen/main.php

International Code of Zoological Nomenclature adopted by the International Union of Biological Sciences (Internet) (1999). London: International Trust for Zoological Nomenclature. (cited 2017 Apr 12). Available from: http://www.nhm.ac.uk/hosted-sites/iczn/code/

Isotti, R., Luiselli, L. \& Fanfani A. (2014). Null model analysis of community structure reveals that patch quality influences the conservation of complex bird communities in mediterranean habitats. Revue d Écologie (Terre Vie), 69(2), 120-130. http://hdl.handle.net/2042/55992

James, F. \& Wamer N. (1982). Relationships between temperate forest bird communities and vegetation structure. Ecology, 63, 159-171. DOI: 10.2307/1937041.

Järvinen, O. \& Väisänen R.A. (1975). Estimating relative densities of breeding birds by the line transect method. Oikos, 26(3), 316-322. DOI: 10.2307/3543502. 
Katsimanis, N., Dretakis, D., Akriotis, T. \& Mylonas M. (2006). Breeding bird assemblages of eastern Mediterranean shrublands: composition, organisation and patterns of diversity. Journal of Ornithology, 147(3), 419-427. DOI: 10.1007/s10336-005-0024-6.

Klausnitzer, B. (1990). Ecology of urban fauna (in Russian). Moscow: Mir.

Kurlavichus, P. (1986). Biotopic distribution of birds in agrarian plantations. Vilnjus: Mokslas.

Lavrov, V., Blinkova, O., Miroshnik, N. \& Ivanenko O. (2016). Synecological principles of diagnostics of transformation of structural and functional organization of forest ecosystems in the evolutionary aspect. Factors in Experimental Evolution Organisms, 18, 186-190.

Lewis, K. \& Starzomski B. (2015). Bird communities and vegetation associations across a treeline ecotone in the Mealy Mountains, Labrador, which is an understudied part of the boreal forest. Can. J. Zool., 93(2), 477-486. DOI: $10.1139 /$ cjz-2014-0309.

MacArthur, R. \& MacArthur J. (1961). On bird species diversity. Ecology, 42, 594-598. DOI: 10.2307/1932254.

Magurran, A. (1998). Ecological diversity and its measurement. New Jersey: Princeton University Press.

Marczynski, W. (1977). Statistical-topographical and historical description of Podolsk province with drawings and maps (in Ukraniain). Kiev: Nauk Dumka.

Martin, J.-L. \& Joron M. (2003). Nest predation in forest birds: influence of predator type and predator's habitat quality. Oikos, 102, 641-653. DOI: 10.1034/j.1600-0706.2003.12040.x.

Marzluff, J., Gehlbach, F. \& Manuwal D. (1998). Urban environments: influences on avifauna and challenges for the avian conservationist. In J.M. Marzluff \& R. Sallabanks (Eds.), Avian conservation: research and management. Washington: Island Press.

Migunova, E. (1993). Forests and forest land (quantitative assessment of relationships) (in Russian). Moscow: Ecology.

Mikusinski, G., Gromadzki, M. \& Chylarecki P. (2001). Woodpeckers as indicators of forest bird diversity. Conserv. Biol., 15(1), 208-217. DOI: 10.1111/j.1523-1739.2001.99236.x.

Mirkin, V., Naumova, L. \& Solomeshh A. (2002). The modern science of vegetation (in Russian). Moscow: Logos.

Moreno-Rueda, G. \& Pizzaro M. (2009). Relative influence of habitat heterogeneity, climate, human disturbance, and spatial structure on vertebrate species richness in Spain. Ecol. Res., 24(2), 335-344. DOI: 10.1007/s11284008-0509-x.

Mosyakin, S. \& Fedoronchuk M. (1999). Vascular plants of Ukraine a nomenclatural checklist. Kyiv: MG Kholodny Institute Botany.

Muntaner, J., Ferrer, X. \& Martınaez-Vilalta A. (1983). Atles dels ocells nidificants de Catalunya i Andorra. Barcelona: Ketres Editora.

Neshataev, J. (1987). Methods of analysis of geobotanical materials (in Russian). Leningrad: University.

Novikov, G. (1953). Field studies on the ecology of terrestrial vertebrates (in Russian). Moscow: Soviet Science.

O'Connor, R. (1981). Habitat correlates of bird distribution in British census plots. Studies in Avian Biology, 6, $533-537$.

Pereira, P., Godinho, C., Roque, I., Marques, A., Branco, M. \& Rabaça J.E. (2014). Time to rethink the management intensity in a Mediterranean oak woodland: the response of insectivorous birds and leaf-chewing defoliators as key groups in the forest ecosystem. Ann. For Sci., 71(1), 25-32. DOI: 10.1007/s13595-012-0227-y.

Polyakov, A. (2009). Crimea forest formations and their ecological role (in Russian). Kharkiv: New Word.

Poulsen, B. (2002). Avian richness and abundance in temperate Danish forests: tree variables important to birds and their conservation. Biodivers. Conserv., 11, 1551-1566. DOI: 10.1023/A:1016839518172.

Rabotnov, T. (1992). Phytocenology (in Russian). Moscow: Science.

Ramenskii, L. (1971). Problems and methods of studying vegetation cover (in Russian). Leningrad: Nauka.

Robles, H., Ciudad, C. \& Matthysen E. (2011). Tree-cavity occurrence, cavity occupation and reproductive performance of secondary cavity-nesting birds in oak forests: The role of traditional management practices. For. Ecol. Manag., 261(8), 1428-1435. DOI: 10.1016/j.foreco.2011.01.029.

Robles, H., Ciudad, C. \& Matthysen E. (2012). Responses to experimental reduction and increase of cavities by a secondary cavity-nesting bird community in cavity-rich Pyrenean oak forests. For. Ecol. Manag., 277, 46-53. DOI: 10.1016/j.foreco.2012.04.017.

Rodewald, A. \& Abrams M. (2002). Floristics and avian community structure: implications for regional changes in eastern forest composition. J. For. Sci., 48, 267-272.

Roth, R. (1976). Spatial heterogeneity and bird species diversity. Ecology, 57, 773-782. DOI: 10.2307/1936190.

Rusin, L. (2003). Monitoring of recreational forests (in Russian). Moscow: Ran.

Salek, M., Svobodova, J. \& Zasadil P. (2010). Edge effect of low-traffic forest roads on bird communities in second- 
ary production forests in central Europe. Lands. Ecol., 25(7), 1113-1124. DOI: 10.1007/s10980-010-9487-9.

Sanchez, S., Javier-Cuervo, J. \& Moreno E. (2012). Vegetation structure in beech-fir forests: effects on the avian community. Revue d Écologie. (Terre Vie), 67, 213-222. http://hdl.handle.net/2042/55914

Sangster, G., Collinson, J., Crochet, P., Kirwan, G., Knox, A., Parkin, D. \& Votier S. (2016). Taxonomic recommendations for Western Palearctic birds: 11th report. Ibis, 158(1), 206-212. DOI: 10.1111/ibi.12322.

Sanitary Forest Regulation in Ukraine (1995). Resolution of government of Ukraine. No. 555 (July 27, 1995).

Sekercioğlu, C. (2002). Effects of forestry practices on vegetation structure and bird community of Kibale National Park, Uganda. Biol. Conserv., 107(2), 229-240. DOI: 10.1016/S0006-3207(02)00097-6.

Sekercioğlu, C. (2006). Increasing awareness of avian ecological function. Trends Ecol. Evol., 21(8), 464-471. DOI:10.1016/j.tree.2006.05.007

Seymour, C., Simmons, R., Joseph, G. \& Slingsby J. (2015). On bird functional diversity: species richness and functional differentiation show contrasting responses to rainfall and vegetation structure in an Arid Landscape. Ecosystems, 18(6), 971-984. DOI: 10.1007/s10021-015-9875-8.

Shirihai, H., Gargallo, G. \& Helbig A. (2001). Sylvia Warblers. In Ch. Helm (Ed.), Identification, taxonomy and phylogeny of the Genus Sylvia. London: Black.

Stefanova, M. \& Salek M. (2014). Effects of integrated farming on herbal and bird species diversity in Czech agricultural landscapes. Pol. J. Ecol., 62, 147-162. DOI: 10.3161/104.062.0114.

Snow, D. \& Perrins C. (1998). The birds of the Western Palearctic. Vol. 2: Passerines. Oxford: Oxford University Press.

Shupova, T. (2001). The present state of the number of roller (Coracias garrulus). Visn. Dnipropetr Univ. Ser. Biol. Ecol., 9(2), 119-123.

Shupova, T. \& Chaplygina A. (2016). The avifauna of the reserve of national importance «Luchkivskiy». J. Karazin Kharkiv National Univ. Ser. Biol., 26, 148-156.

Shupova, T. (2017). The transformation of the diversity of avifauna under the influence of recreational load. Biosyst. Divers., 25(1), 45-51. DOI: 10.15421/011707.

Tews, J., Brose, U., Grimm, V., Tielbörger, K., Wichmann, M.C., Schwager, M. \& Jeltsch F. (2004). Animal species diversity driven by habitat heterogeneity/diversity: the importance of keystone structures. J. Biogeogr., 31(1), 79-92. DOI: 10.1046/j.0305-0270.2003.00994.x.

Thiollay, J. (1997). Disturbance, selective logging and bird diversity: aneotropical forest study. Biodivers. Conserv., 6 , 1155-1173. DOI: 10.1023/A:1018388202698.

Virkkala, R. (2006). Why study woodpeckers? The significance of woodpeckers in forest ecosystems. Ann. Zool. Fenn., 43(2), 82-85.

Walther, B. (2002). Vertical stratification and use of vegetation and light habitats by Neotropical forest birds. Journal of Ornithology, 143, 64-81. DOI: 10.1007/BF02465460.

Wen, W., Maruyama, N., Bo-Wen, L., Morimoto, H. \& Zhong-Xin G. (2002). Relationships between bird communities and vegetation structure in Honghuaerji, northern inner Mongolia. J. For. Res., 13(4), 294-298. DOI: $10.1007 /$ BF02860095.

Westphal, M., Field, S., Tyre, A., Paton, D. \& Possingham H. (2003). Effects of landscape pattern on bird species distribution in the Mt. Lofty Ranges, South Australia. Landsc. Ecol., 18, 413-426. DOI: 10.1023/A:1026115807529.

Whelan, C., Wenny, D. \& Marquis R. (2008). Ecosystem services provided by birds. Ann. N. Y. Acad. Sci., 1134(1), 25-60. DOI: 10.1196/annals.1439.003.

Wilson, M. (1974). Avian community organization and habitat structure. Ecology, 55, 1017-1029. DOI: $10.2307 / 1940352$.

Wilson, M., de Santo, T. \& Sabag C. (1994). Avian community of fragmented south-temperate rainforests in Chile. Conserv. Biol., 8, 508-520. DOI: 10.1046/j.1523-1739.1994.08020508.x.

Wilson, M., Pithon, J., Gittings, T., Kelly, T., Giller, P. \& O'Halloran J. (2006). Effects of growth stage and tree species composition on breeding bird assemblages of plantation forests. Bird Study, 53(3), 225-236. DOI: $10.1080 / 00063650609461437$.

Zavjalov, E., Shljahtin, G., Tabachishin, V. \& Jakushev N. (2005). Ecological-faunistic characteristic by avifauna of the north of Lower Volga region. J. Saratov Univ. Ser. Chem. Biol. Ecol., 2, 49-59. 
Appendix 1. Conservation status of birds in experimental plots.

\begin{tabular}{|c|c|c|c|c|c|}
\hline Species (scientific name) & EP1 & EP2 & EP3 & EP4 & The conservation status \\
\hline Ardea cinerea & - & - & - & $\mathrm{O}$ & Bk3 \\
\hline Anas platyrhynchos & - & - & - & $\mathrm{O}$ & Bk3; Bo1,2 \\
\hline Accipiter gentilis & - & - & - & $\mathrm{f}$ & Bk2; Bo1,2; W2 \\
\hline Tringa ochropus & - & - & - & $\mathrm{n}, \mathrm{f}$ & Bk2; Bo1,2 \\
\hline Columba palumbus & $\mathrm{f}$ & $\mathrm{n}, \mathrm{f}$ & - & $\mathrm{n}, \mathrm{f}$ & - \\
\hline Strix aluco & - & - & - & $f$ & Bk2; W2 \\
\hline Alcedo atthis & - & - & - & $\mathrm{n}$ & Bk2 \\
\hline Picus canus & - & $\mathrm{f}$ & - & $\mathrm{n}, \mathrm{f}$ & Bk2 \\
\hline Dryocopus martius & - & & - & $\mathrm{n}, \mathrm{f}$ & $\mathrm{Bk} 2$ \\
\hline Dendrocopos major & $\mathrm{f}$ & $\mathrm{f}$ & - & $\mathrm{n}, \mathrm{f}$ & $\mathrm{Bk} 2$ \\
\hline Dendrocopos syriacus & - & $\mathrm{n}, \mathrm{f}$ & - & - & Bk2 \\
\hline Dendrocopos medius & $\mathrm{f}$ & $\mathrm{f}$ & $\mathrm{n}, \mathrm{f}$ & $\mathrm{n}, \mathrm{f}$ & Bk2 \\
\hline Dendrocopos minor & - & - & $\mathrm{n}, \mathrm{f}$ & $\mathrm{n}, \mathrm{f}$ & Bk2 \\
\hline Lullula arborea & - & - & - & $\mathrm{n}, \mathrm{f}$ & Bk3 \\
\hline Anthus trivialis & - & - & - & $\mathrm{n}, \mathrm{f}$ & Bk2 \\
\hline Motacilla alba & - & - & - & $\mathrm{n}, \mathrm{f}$ & Bk2 \\
\hline Oriolus oriolus & - & $\mathrm{n}, \mathrm{f}$ & $\mathrm{n}, \mathrm{f}$ & $\mathrm{n}, \mathrm{f}$ & Bk2 \\
\hline Sturnus vulgaris & $f$ & - & - & - & - \\
\hline Garrulus glandarius & - & - & $\mathrm{n}, \mathrm{f}$ & - & - \\
\hline Troglodytes troglodytes & - & - & - & $\mathrm{n}, \mathrm{f}$ & Bk2 \\
\hline Acrocephalus arundinaceus & $\mathrm{f}$ & - & - & - & Bk2 \\
\hline Hippolais icterina & - & - & $\mathrm{n}, \mathrm{f}$ & $\mathrm{n}, \mathrm{f}$ & $\mathrm{Bk} 2$ \\
\hline Sylvia atricapilla & - & $\mathrm{f}$ & - & $\mathrm{n}, \mathrm{f}$ & Bk2 \\
\hline Phylloscopus collybita & - & $f$ & $\mathrm{n}, \mathrm{f}$ & $\mathrm{n}, \mathrm{f}$ & Bk2 \\
\hline Phylloscopus sibilatrix & - & - & - & $\mathrm{n}, \mathrm{f}$ & Bk2 \\
\hline Ficedula hypoleuca & - & - & - & $\mathrm{n}, \mathrm{f}$ & $\mathrm{Bk} 2 ; \mathrm{Bo} 2$ \\
\hline Ficedula albicollis & - & - & $\mathrm{n}, \mathrm{f}$ & - & $\mathrm{Bk} 2 ; \mathrm{Bo} 2$ \\
\hline Ficedula parva & - & $\mathrm{f}$ & - & $\mathrm{n}, \mathrm{f}$ & Bk2; Bo2 \\
\hline Muscicapa striata & - & $\mathrm{n}, \mathrm{f}$ & $\mathrm{n}, \mathrm{f}$ & $\mathrm{n}, \mathrm{f}$ & $\mathrm{Bk} 2 ; \mathrm{Bo} 2$ \\
\hline Erithacus rubecula & - & $\mathrm{f}$ & $\mathrm{n}, \mathrm{f}$ & $\mathrm{n}, \mathrm{f}$ & $\mathrm{Bk} 2 ; \mathrm{Bo} 2$ \\
\hline Luscinia luscinia & - & $\mathrm{f}$ & $\mathrm{n}, \mathrm{f}$ & $\mathrm{n}, \mathrm{f}$ & $\mathrm{Bk} 2 ; \mathrm{Bo} 2$ \\
\hline Turdus pilaris & - & - & - & $\mathrm{n}, \mathrm{f}$ & Bk3; Bo2 \\
\hline Turdus merula & $f$ & $\mathrm{n}, \mathrm{f}$ & $\mathrm{n}, \mathrm{f}$ & $\mathrm{n}, \mathrm{f}$ & $\mathrm{Bk} 3 ; \mathrm{Bo} 2$ \\
\hline Turdus philomelos & - & $\mathrm{n}, \mathrm{f}$ & $\mathrm{n}, \mathrm{f}$ & $\mathrm{n}, \mathrm{f}$ & $\mathrm{Bk} 3 ; \mathrm{Bo} 2$ \\
\hline Aegithalos caudatus & - & $\mathrm{f}$ & - & $\mathrm{n}, \mathrm{f}$ & Bk2 \\
\hline Parus palustris & - & - & - & $\mathrm{n}, \mathrm{f}$ & $\mathrm{Bk} 2$ \\
\hline Parus ater & - & - & - & $\mathrm{n}, \mathrm{f}$ & $\mathrm{Bk} 2$ \\
\hline Parus caeruleus & - & - & - & $\mathrm{n}, \mathrm{f}$ & $\mathrm{Bk} 2$ \\
\hline Parus major & $\mathrm{f}$ & $\mathrm{n}, \mathrm{f}$ & $\mathrm{n}, \mathrm{f}$ & $\mathrm{n}, \mathrm{f}$ & Bk2 \\
\hline Sitta europaea & $f$ & $\mathrm{n}, \mathrm{f}$ & $\mathrm{n}, \mathrm{f}$ & $\mathrm{n}, \mathrm{f}$ & $\mathrm{Bk} 2$ \\
\hline Certhia familiaris & - & - & $\mathrm{n}, \mathrm{f}$ & $\mathrm{n}, \mathrm{f}$ & $\mathrm{Bk} 2$ \\
\hline Fringilla coelebs & $\mathrm{f}$ & $\mathrm{n}, \mathrm{f}$ & $\mathrm{n}, \mathrm{f}$ & $\mathrm{n}, \mathrm{f}$ & Bk3 \\
\hline Coccothraustes coccothraustes & - & $\mathrm{f}$ & $\mathrm{n}, \mathrm{f}$ & $\mathrm{n}, \mathrm{f}$ & Bk2 \\
\hline
\end{tabular}

Notes: $\mathrm{O}$ - overflight in EP; $\mathrm{f}$ - feeding; $\mathrm{n}$ - nesting; Bk2, Bk3 - categories of the Berne Convention; Bo1,2 - categories of the Bonn Convention; W2 - category of the Washington Convention. 